\title{
Motives for Remittances Change During the Financial Crisis in Bosnia and Herzegovina
}

\begin{abstract}
Bosnia and Herzegovina $(\mathrm{BiH})$, a country that relies on a significant amount of remittance inflows, has experienced a drop in these inflows as a consequence of the global economic crisis. This paper aims to analyse whether and how this decrease is related to a change in motives for sending remittances. The change in motives will be analysed by exploring the interaction between social transfers and remittances using two household datasets, from 2007 (before the crisis) and 2011 (during the crisis), respectively. The analysis is based on the estimation of two model specifications, one that controls for the motives' non-monotonicity and another that does not. Compared to previous studies, this paper estimates the non-monotonic 'crowding-out' effect via an innovative empirical model specification. Its findings suggest that the predominant motive for sending remittances to $\mathrm{BiH}$ before the crisis was exchange, while during the crisis the senders of remittances were more altruistic. In addition, the results from the model on non-monotonicity of motives support the hypothesis that as a consequence of the economic crisis, transfer motives are changing in ways that are different for poor and non-poor recipients of remittances.
\end{abstract}

Nermin Oruč is Senior Research Analyst at Impaq International Sarajevo.

Amina Tabaković is Junior Researcher at the Centre for Economic Development and Research (CEDaR) Sarajevo.

\section{Introduction}

Up to now, the investigation of motives for sending remittances has commonly been conducted within a framework that analyses the 'crowding-out' effect influencing the relation between social transfers and remittances, in which a negative relationship would suggest altruistic motives, whereas a positive relationship would be indicated by other motives such as insurance, inheritance, or the exchange of services. ${ }^{1}$ The ongoing global economic crisis offers a unique

${ }^{1}$ In the 'crowding-out' literature it is common to label all non-altruistic motives 'exchange'. The same terminology is applied in this paper. Cf. Donald Cox / Bruce E. Hansen / Emmanuel Jimenez, How Responsive Are Private Transfers to Income? Evidence from a Laissez-Faire Economy, Journal of Public Economics 88, No. 9 (2004), 2193-2219. An earlier version of this 
opportunity to investigate whether and how the motives to send remittances were changed by the crisis, which affected both their senders and their recipients. Analysis of two Household Budget Survey (HBS) datasets from Bosnia and Herzegovina (BiH), one from 2007 (before the crisis) and another from 2011 (during the crisis), allows the estimation of a model for the relationship between social transfer receipts and remittances to households. Comparison of findings from data collected in these two years yields insights into possible changes in the motives for sending remittances from 2007 to 2011, a period conspicuously marked by the onset of the 2008 economic crisis and its continuing effects. It would not be appropriate to conclude, on the basis of these results, that the change in motives was due to the crisis, since many other, unobservable factors might have influenced the motives for sending remittances; however, the comparison of motives between the two yearlong periods can provide useful insights.

During the war in BiH in the 1990s, about one quarter of the country's total population fled the country. ${ }^{2}$ Even today, it is estimated that every third Bosnian lives abroad. ${ }^{3}$ As a result, the percentage of $\mathrm{BiH}^{\prime}$ s GDP derived from remittances (around 13\%) is among the highest in the world. ${ }^{4}$ Overall social transfers in $\mathrm{BiH}$ amount to about $14 \%$ of its GDP, the majority of which goes to pensions and health-care services. ${ }^{5}$ But in addition, a large proportion of these transfers is devoted to non-insurance-based benefits, among them veterans' benefits, child-care allowances, and other forms of social assistance.

This situation, in which a nation has significant private and public transfers, motivates an analysis of the possible interaction between such transfers. The link between receipt of social and private transfers is known as the crowdingout effect. ${ }^{6}$ The sign of this effect, in addition, helps reveal possible motives for the sending of remittances. If the sign is negative, i.e. any increase in social transfers received by a household decreases the remittance income received; this suggests that remittances are driven by senders' altruistic motives. On the contrary, if remittances are driven by the exchange motive, they will increase when social transfers increase.

paper was presented during the 14th Global Development Network Conference 'Inequality, Social Protection and Inclusive Growth', 19-21 June 2013, Manila, Philippines.

${ }^{2}$ Izet Ibreljić et al., Migration Flows in Bosnia-Herzegovina after 1992. Paper presented at the 46th ERSA Congress (2006), Volos, Greece, https://ideas.repec.org/p/wiw/wiwrsa/ ersa06p173.html. All internet references were accessed on 5 February 2016.

${ }^{3}$ BiH Ministry of Security, BiH Migration Profile for the Year 2013, Sarajevo, May 2014, http://msb.gov.ba/PDF/MIGRATION\%20PROFILE_2014_ENG.pdf.

${ }_{4}^{4}$ BiH Ministry of Security, BiH Migration Profile for the year 2013.

${ }^{5}$ Nermin Oruč, Analysis of Social Protection System in BiH, UNDP Report, 2013.

${ }^{6}$ John Gibson / Susan Olivia / Scott Rozelle, How Widespread Are Non-Linear Crowding Out Effects? The Response of Private Transfers to Income in Four Developing Countries, Applied Economics 43, No. 27 (2010), 4053-4068. 
Remittances are well known as a countercyclical international financial flow: their inflow to a country increases during economic downturns because migrants abroad send more money to their families at home if their need for support increases. The global economic crisis has changed this dynamic, because it has affected recipients and senders of remittances. Therefore, the cyclicality of these flows is an empirical question.

This study investigates the presence of the crowding-out effect in Bosnia and Herzegovina, and its change between 2007 and 2011, to answer the question: How do the motives for sending remittances change when senders face economic difficulties? The social transfers to be analysed here are restricted to non-contribution-based social transfers, such as veterans' benefits and child-care allowances, because contribution-based benefits, such as unemployment benefits and pensions, cannot-unlike non-contribution-based transfers-be considered exogenous sources of income. As this study's key objective is analysis of the crowding-out effect, then contribution-based benefits, which are received as alternatives to wages, should not be considered exogenous sources of income that increase their recipients' overall incomes.

The paper is structured as follows. The next section reviews the literature on social transfers' crowding-out effect on remittances. The third section briefly explains the characteristics of Bosnia-Herzegovina's social security system and the inflows of remittances to the country. The fourth section provides the theoretical model for the non-monotonic crowding-out effect and presents new specifications for two empirical models: one that controls for such an effect, and another that does not. The method and the data used for these models are also described. Section five presents results of the estimation of different model specifications. Finally, section six explains the policy implications of this study's results.

\section{Literature on the Crowding Out Effect}

Literature on social transfers' crowding-out effect on remittances has been concerned with investigating its direction and the linearity of senders' motives. Therefore, the theory about the effect has been empirically tested in cross-sectional settings. The ongoing global economic crisis offers a unique opportunity to investigate whether and how the motives for remittances were changed by the massive international downturn - a crisis that affected senders and recipient of remittances alike. This paper is the first contribution to the empirical literature that analyses the change in motives for the sending of remittances as a consequence of the recent global economic crisis.

The empirical literature analysing motives for sending remittances primarily uses the crowding-out framework, where the sign of the relationship between 
receipt of remittances and change in income, usually as a result of a change in the receipt of social transfers, is used to reveal possible motives for the sending of remittances. Remittances can be motivated by either altruism or exchange. ${ }^{7}$ Becker's conception of altrustic motives for transfers is based on the idea of interdependent preferences. According to this idea, people have preferences about what others consume (e.g. parents have preferences about what their children consume) and consequently, the utility of transfers depends not only on their own consumption but also on that of others. Thus a migrant will increase the amount of remittance payments sent to family members left behind once their income has been negatively affected by adverse conditions in the migrants' home country. So if these transfers are motivated by altruism, a decrease in a recipient's income (as a result of crisis or reduced social transfers) will increase private transfers. This effect is interpreted as the crowding out of private transfers by public transfers. ${ }^{8}$ This crowding-out effect implies that social transfers' positive effects can be neutralised by remittances, as the giving of support to vulnerable groups - the intended outcome of social transfers - will, at least partially, be transferred to senders of remittances. ${ }^{9}$

The opposite effect is expected if the sending of remittances is motivated by exchange, resulting in remittances being 'crowded in' by public transfers. ${ }^{10}$ If private transfers are predominantly motivated by exchange, meaning that such transfers are used as payment for the provision of certain services by a recipient to a sender, then the sign of the relationship between them is positive, because the rise in income of the provider of services through the receipt of social transfers increases the 'price' of such services. Other subtypes of the 'exchange' motive

7 Gary S. Becker, A Theory of Social Interactions, Journal of Political Economy 82, No. 6 (1974), 1063-1093, http://msap-unlam.ac.id/download/bahan_bacaan/A\%20Theory\%20of\%20 Social\%20Interactions.pdf. B. Douglas Bernheim / Andrei Shleifer / Lawrence H. Summers, The Strategic Bequest Motive, Journal of Political Economy 93, No. 6 (1985), 1045-1076, http://darp. lse.ac.uk/papersdb/bernheim-shleifer-summers_\%28jpole_85\%29.pdf. As explained above, the 'crowding-out' literature commonly describes all non-altruistic motives as 'exchange', whereas other literature on remittances recognises a number of subtypes of exchange, e.g. inheritance, exchange of services, insurance, and loan repayment.

8 Donald Cox, Motives for Private Income Transfers, Journal of Political Economy 93, No. 3 (1987), 508-546.

9 Joseph G. Altonji / Fumio Hayashi / Laurence J. Kotlikoff, Parental Altruism and Inter Vivos Transfers. Theory and Evidence, Journal of Political Economy 105, No. 6 (1997), 1121-1166.

10 Joseph G. Altonji / Fumio Hayashi / Laurence J. Kotlikoff, The Effects of Income and Wealth on Time and Money Transfers between Parents and Children, in: Andrew Masson / Georges Tapinos, eds, Sharing the Wealth. Demographic Change and Economic Transfers between Generations, Oxford 2000, 306-357; Cox, Motives for Private Income Transfers; Donald Cox, Intergenerational Transfers and Liquidity Constraints, Quarterly Journal of Economics 105, No. 1 (1990), 187-217; J. Edward Taylor, Do Government Programs 'Crowd In' Remittances?, in: Rodolfo O. de la Garza / Briant Lindsay B. Lowell, eds, Sending Money Home. Hispanic Remittances and Community Development, Oxford 2002, 189-214. 
can be explained in the same way. For example, if remittances are motivated by the sender's self-interested intention to increase inheritance claims, then the recipient's increase in income also increases the expected gain of inheritance and, consequently, remittance transfers can be seen as an 'investment'. During a global economic crisis, however, the interplay of changes in income and social transfer among remittance senders and their recipients complicates the expected crowding-out effect. Moreover, such changes may affect people's motivation to send remittances, which need to be tested empirically.

Up to now, the majority of empirical studies have failed to find a strong crowding-out effect between social transfers and remittances. ${ }^{11}$ One explanation might be that most of these studies did not account for the possibility of a non-monotonic relationship between public and private transfers. ${ }^{12}$ An increase in income may cause the motives for transfers to change, thus causing the sign of the relationship between public and private transfers to be different at different levels of recipients' income. Such linear models are not correctly specified and therefore cannot capture the true crowding-out effect. In addition, empirical evidence from developed countries that possess a long history of public transfers that may already have replaced private transfers might be misleading. Therefore, recent studies have focused on the collection of evidence from developing countries, allowing for a non-monotonic relationship between public and private transfers. Cox et al. investigated this possibility by a threshold model and estimated the transfer derivatives to be -0.4 for the poorest households and almost zero for richer households in the Philippines. ${ }^{13}$ In a study of the relationship between public pensions for the elderly and private transfers in South Africa, Jensen estimates that for each rand increase in public pension income, transfers made by people's children were reduced by $0.25-0.30$ Rand. ${ }^{14}$ Although recent studies have addressed the issue of change in motives across income distribution, the present study is the first to also address the change in motives over time.

11 Joseph G. Altonji / Fumio Hayashi / Laurence J. Kotlikoff, Parental Altruism and Inter Vivos Transfers; Donald Cox / Georges Jakubson, The Connection between Public Transfers and Private Interfamily Transfers, Journal of Public Economics 57, No. 1 (1995), 129-167.

12 Pedro Albarran / Orazio Pietro Attanasio, Do Public Transfers Crowd Out Private Transfers? Evidence from a Randomized Experiment in Mexico, WIDER Discussion Paper 6/2002, https://www.wider.unu.edu/publication/do-public-transfers-crowd-out-privatetransfers.

${ }^{13}$ Cox / Hansen / Jimenez, How Responsive Are Private Transfers to Income?

14 Robert T. Jensen, Do Private Transfers 'Displace' the Benefits of Public Transfers? Evidence from South Africa, Journal of Public Economics 88, No. 1-2 (2003), 89-112. 


\section{Remittances and Social Protection in Bosnia and Herzegovina. Background}

\section{Remittances}

As stated above, the large forced migration during the war period in $\mathrm{BiH}$ in the 1990s put it among the leading countries in terms of receiving remittances as a share of GDP. Annual inflows of international remittances, as made through the banking system only, totaled around 2 billion euros in 2011. These remittance inflows provide a significant source of income for a large proportion of $\mathrm{BiH}^{\prime} \mathrm{s}$ population. Moreover, their total is six times larger than foreign direct investments (FDI) and three times larger than the development assistance it has been given. Data about remittance inflows in the period 2002-2011, based on both the BiH Central Bank's and the World Bank's estimates, are presented in Table 1.

There is limited evidence on the use of remittances in Bosnia. The evidence generally suggests that the majority of remittances are used for consumption. In 2005, Lianos reported the results from a survey of returned migrants, which showed that they mainly used their repatriated savings for current consumption, although a large portion $(22.3 \%)$ was also used for the education of children. ${ }^{15}$ In addition, $27.8 \%$ of respondents answered they used these funds for savings, which probably means that they will be used for other purposes later. Another analysis, presented by de Zwager and Gressmann based on data from a 2009 IOM/IASCI survey, reported that the majority of Bosnian migrants remit money back home $(67.3 \%$ of migrants in the EU, $55.1 \%$ of migrants elsewhere in the Yugoslav successor statesia, and $63.6 \%$ of migrants in the United States, Canada, and Australia). ${ }^{16}$ The average annual amount of remittances that migrants in the EU send to $\mathrm{BiH}$ is 2,800 euros, while migrants elsewhere in the former Yugoslavia send considerably less, only 1,200 euros. On average, these remittances are transferred in 4.4 transfers. Most (77\%) are sent through informal channels. The most important purpose of remittances is the support of parents (40\%) and other family members (20\%).

The analysis of the HBS data shows that female-headed households, though more likely to receive remittances than male-headed households, receive on average less in remittance payments. Also, remittances to female-headed households

15 Theodore P. Lianos, Migration in the Balkans, Department of Economics Athens University of Economics and Business, 9 May 2005, http://siteresources.worldbank.org/PGLP/Resources/ Theodore_Lianos.doc.

16 Nicolaas de Zwager/Wolfgang Gressmann, Maximising the Development Impact of Migration-Related Financial Flows and Investment from Austria to Bosnia and Herzegovina, International Agency for Source Country Information (IASCI) and International Organisation for Migration (IOM) Report, prepared for the Ministry for Human Rights and Refugees of Bosnia and Herzegovina, 2009, 66, http://www.mhrr.gov.ba/iseljenistvo/Istrazivanja/default. aspx?id=2787\&langTag=bs-BA. 
Table 1. Remittances in Bosnia and Herzegovina, annual inflow, in millions of euro.

\begin{tabular}{|l|c|c|c|c|c|c|c|c|c|c|}
\hline & 2002 & 2003 & 2004 & 2005 & 2006 & 2007 & 2008 & 2009 & 2010 & 2011 \\
\hline BiH Central Bank & 1,006 & 1,009 & 1,185 & 1,186 & 1,262 & 1,417 & 1,289 & 1,069 & 1,027 & 1,047 \\
\hline World Bank & 1,131 & 1,297 & 1,536 & 1,514 & 1,645 & 2,001 & 2,028 & 1,950 & 1,697 & 1,524 \\
\hline
\end{tabular}

Sources: BiH Central Bank statistics, World Bank statistics, respectively.

have a larger share in household consumption. Poor people on average are more likely to receive remittances than those who are not poor, but their remittance payments are on average less. Also, remittances have a greater share in household consumption for the poor than for those who are not poor households. The same applies for households in the Republika Srpska entity and in rural areas, although remittances have a lower share of household consumption in the latter.

\section{Social Protection}

The social security system in BiH includes both contributory (insurance-based) and non-contributory (non-insurance based) social protection programmes. As in most countries, contributory or social insurance programmes are based on regular financial contributions by beneficiaries that provide protection against a set of predefined risks: e.g. ill-health, old age, disability, and unemployment. Non-contributory or social assistance programmes are based on two main categories: those targeting the poor population (means-tested programmes) and those not targeting the poor, which may impose further conditions governing access to and exercise of beneficiary rights (conditionality). Benefits based on insurance include a) benefits from pensions and disability insurance, b) benefits from health insurance, and c) benefits from unemployment insurance. Besides these formal types of benefits, remittances as an informal form of social insurance are also very important in $\mathrm{BiH}$.

$\mathrm{BiH}$ spends roughly $24 \%$ of GDP on its social protection programmes, including social insurance and social assistance programmes but excluding unemployment benefits. However, the level of spending is not the best indicator of the quality, effectiveness, or feasibility of its programmes. The largest share in the total expenditure on social protection programmes are social protection programmes based on contributions, i.e. health protection programmes (10.2\%) and pensions (10.1\%). Social assistance programmes cost $3.9 \%$ of GDP, more expensive proportionally than those in the EU and the western Balkan countries. Despite significant fiscal outlays, non-contributory transfer coverage is low; a comparatively large share of benefits goes to those in richer quintiles. Non-contributory social benefits have a negligible impact on poverty, and nontargeted programmes have reached the limits of the fiscal envelope, to the point 
of crowding out targeted ones. According to a World Bank report, $12.4 \%$ of the $\mathrm{BiH}$ population reports receiving benefits in the form of non-contributory social assistance transfers (civilian or veteran-related). ${ }^{17}$ However, only a small fraction of the poor actually receives the benefit. A much larger share of the population reports receiving social insurance benefits (40\%), with about half reporting that they receive some type of benefits (contribution-based social insurance and/or non-contributory social transfers).

\section{Modelling the Crowding-Out Effect}

This paper analyses the possible crowding-out effect of social transfers on remittances in order to find evidence about the dominant motives for sending remittances, as well as how these motives have changed during the recent global economic crisis. Its findings reveal the possible predominant motives for remitting by Bosnians and their dynamics over time, which can indirectly be interpreted as effects of the global economic crisis on these motives. ${ }^{18}$

Two different model specifications are outlined here. In the first specification, the motives of remittances are assumed to be monotonic. In the second, assuming that the motives for remittances are non-monotonic, the impact of social transfers on remittances was estimated based on the theoretical description of the relationship provided by Cox et al. ${ }^{19}$ Cox et al. hypothesised that the relationship between social transfers and remittances should be negative at low levels of income, then begin to increase at some threshold level (K) such as the poverty line, as exchange motives supplant altruistic motives for the sending of remittances. But as income increases, the presence of exchange motives causes remittances first to increase (up to the recipient's income level, depicted by I' in figure 1) and then to decrease and eventually cease (at the income level depicted by $\mathrm{I}^{\prime \prime}$ ), making the relationship between social transfer and remittances negative in the first part and having an inverse U-shape in the second. Cox et al. suggest that the appropriate specification of the empirical model needs to be nonlinear to capture such a relationship and to account for non-monotonic motives by specifying a point where the break occurs. Moreover,

17 World Bank, Social Assistance Transfers in Bosnia and Herzegovina. Moving Towards a More Sustainable and Better Targeted Safety Net, World Bank Report, Washington/ DC, 30 April 2009, http://www-wds.worldbank.org/external/default/WDSContentServer/ WDSP/IB/2009/07/13/000334955_20090713024120/Rendered/PDF/AAA330BA0P11291C0Disclosed071101091.pdf.

18 We compare results on motives for sending remittances in two years that coincide with periods before and during the crisis. As we do not control for all factors that might have influenced these motives over time, we cannot claim a causal relationship between the crisis and the motives for sending remittances, as there are other possible causes.

${ }^{19}$ Cox / Hansen / Jimenez, How Responsive Are Private Transfers to Income? 


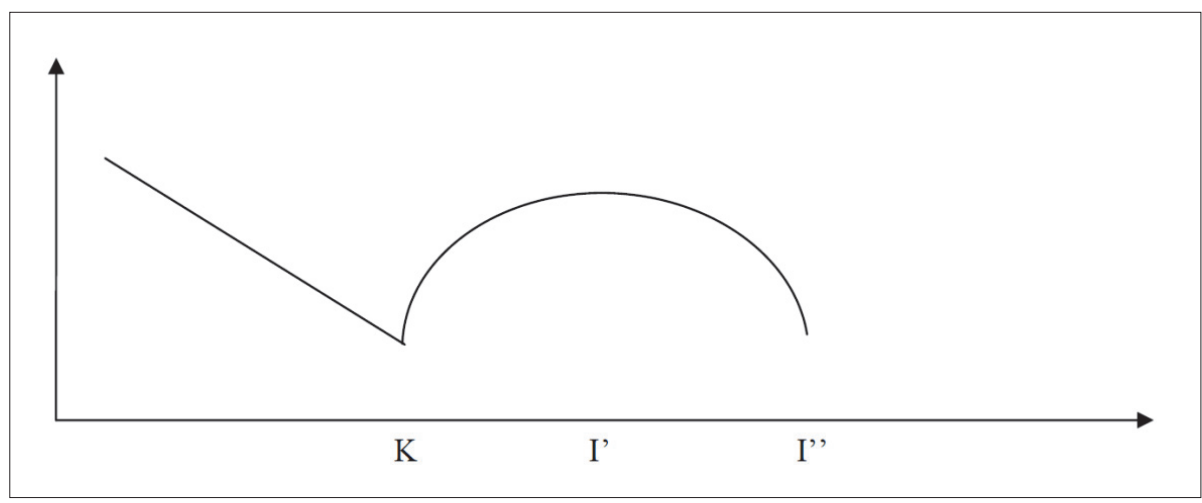

Figure 1. Non-monotonic relationship between social transfers and remittances. Source: Cox / Hansen / Jimenez, How Responsive Are Private Transfers to Income?, 2199.

the break where the receiving of remittances ceases needs to be identified. In terms of model specifications with alternative dependent variables, it should be noted that Cox et al. suggest the relationship outlined above for the amount of remittances received, but not necessarily for the likelihood that remittances will be received, which means that the theoretical discussion presented above of the non-monotonic and non-linear effect of social transfers on remittances should be controlled for in models only where the dependent variable is the amount of remittances.

Compared to previous studies, this paper uses a new approach to the problems of non-monotonic motives for sending remittances. ${ }^{20}$ In the second model specification, the poverty line was chosen as a threshold point where the motives begin to change. We can assume that remittances to lower-income recipients may be more altruistically motivated, so they decrease after an increase in social transfers and their poverty-reduction goal may not necessarily be reached. Remittances to higher-income recipients may be motivated more by exchange and would therefore change in the same direction as social transfers. In such relations, social transfers would increase poverty and inequality among households, particularly when the receipt of remittances by the non-poor is matched with ineffective social transfer policies. There is some evidence to support these ideas, but most studies have been based on the analysis of cross-sectional data, which does not assure an appropriate capture of the dynamic effects of changes in transfers. Therefore, it is necessary to test these ideas by using datasets from different time periods.

${ }^{20}$ As developed in Nermin Oruč, Do Social Transfers 'Crowd-Out' Remittances. The Case of Bosnia, SEEU Review 7, No. 1 (2012), 39-65, http://www.seeu.edu.mk/files/SEEU-Review-7-1.pdf. 


\section{Empirical Specification and Estimation Methods}

In this paper's empirical analysis, the main research question is to be tested by estimations of six different models. The first set of three models (one pooled OLS for both periods, and two for each year separately) is based on the model specification where the relationship between social transfers and remittances is estimated by including only the variable for the amount of social transfers, assuming that motives for remittances are monotonic. A second set of models (using three different sets of data) presents the model specification where the interaction term between amount of social transfers and poverty status of their recipients is used in order to determine non-monotonic transfer motives towards poor and non-poor households, respectively (i.e. to examine the switch from altruism to exchange as motivating remittances); the amount of social transfers are also introduced in a polynomial form in order to test for the possible nonlinearity of the relationship between social transfers and remittances motivated by exchange (i.e. above the poverty threshold).

The model to be estimated in the first part of the empirical analysis is presented by the following equation:

$Y=\beta_{0}+\beta_{1}$ incpens $+\beta_{2} t s t+\beta_{i} \sum h h+u_{i}$

where:

$Y$ - a dependent variable, expressed as an annual monetary amount of remittances received by a household, in increments of thousand Bosnian Marks (BAM);

Incpens - a variable for pre-transfer income, including pensions;

tst-average amount of annual social transfers received by household, in thousand-BAM increments;

hh-set of household demographic characteristics which are hypothesised to influence receipt and amount of remittances, including: household head's gender $(f h h)$, which takes value of 1 if household's head is female; age (age); education level (primedu, secedu, tertedu), where primedu takes value of 1 if household head has a primary education; household size (hhsize); number of children in the household (numkids); marital status (marital), which takes value of 1 if household head is married; and employment status (empl), which takes value of 1 if household head is employed.

The second stage uses a model specification that controls for the non-monotonic and nonlinear effect of social transfers on the remittance income received by households. The first model to be estimated is: 
$Y=\beta_{0}+\beta_{1}$ incpens $+\beta_{2} t s t+\beta_{3} t s t 1 s q+\beta 4$ poor $+\beta_{5} t s t 1$ poor $+\beta_{i} \Sigma h h+u_{i}$

where:

$Y$, incpens, tst, and $h h$-as above, except that tst now shows the relationship between social transfers and remittances among non-poor households;

poor - a dummy variable taking the value of 1 if a person is not poor, 0 otherwise;

tstpoor - interaction variable between variables tst and poor. This variable tests the hypothesis of non-monotonic motives for sending remittances, based on the poverty status of a household;

tstsq-squared value of TSTNP, in order to test the nonlinear effect of social transfers on remittances among the non-poor;

$\mathrm{u}_{\mathrm{i}}$ - error term.

Recent empirical literature has argued that the majority of previous studies of the crowding-out effect did not properly address the endogeneity issue that arises from social transfers being typically targeted towards households that are in particular need of transfers. ${ }^{21}$ But Bosnia-Herzegovina is an interesting case in this respect, as it is an exception to this rule since, as described above, most of the social transfers are category-based and are provided to non-poor people. In addition, several previous studies have suggested the possibility of reverse causality between the receipt of remittances and pre-transfer income, as remittances may affect individuals' incentives to work. ${ }^{22}$ However, studies that controlled for this possibility did not find any significant change in their results.

The two datasets used for empirical analysis in this study are the HBS surveys conducted by the Statistical Agency of Bosnia-Herzegovina in 2007 and 2011. The surveys contain the comprehensive set of information necessary for this analysis. The samples for both surveys were around eight thousand households each. The data are repeated cross-sectional data with different individuals, therefore limiting the options for appropriate estimation methods to be used.

\section{Results}

The results of the three models from specification (1) are presented in Table 2. These results reveal the average influence of social transfers on remittances, or the 'average' (monotonic) motive for sending remittances, regardless of poverty status.

To a large extent, these results are in line with those of previous empirical studies. They provide evidence regarding the expected influence of the key

${ }^{21}$ Albarran / Attanasio, Do Public Transfers Crowd Out Private Transfers?

${ }^{22}$ Cf. Cox / Hansen / Jimenez, How Responsive are Private Transfers to Income? 
Table 2. Estimated coefficients of the alternative models for monotonic motives for sending remittances.

\begin{tabular}{|c|c|c|c|c|}
\hline Variables & Explanation & Period & Coef-07/11 & t-value \\
\hline \multirow[t]{3}{*}{ Incpens1 } & \multirow{3}{*}{$\begin{array}{l}\text { Pre-transfer income } \\
=\text { Income*Pensions }\end{array}$} & 2007-2011 & 6,945 & $2.48^{*}$ \\
\hline & & 2007 & $-31,377$ & $5.67^{* *}$ \\
\hline & & 2011 & 27,437 & $8.66^{* *}$ \\
\hline \multirow[t]{3}{*}{ Tst1 } & \multirow[t]{3}{*}{ Total social transfers } & 2007-2011 & 511,697 & $5.40^{* *}$ \\
\hline & & 2007 & 606,725 & $5.32^{* *}$ \\
\hline & & 2011 & $-383,599$ & 1.92 \\
\hline \multirow[t]{3}{*}{ Fhh_head } & \multirow{3}{*}{$\begin{array}{l}\text { Household head gender } \\
\text { - dummy }\end{array}$} & 2007-2011 & 741,507 & $6.60^{* *}$ \\
\hline & & 2007 & 344,890 & 1.95 \\
\hline & & 2011 & $1.049,608$ & $7.54^{* *}$ \\
\hline \multirow[t]{3}{*}{ Age_head } & \multirow[t]{3}{*}{ Household head age } & 2007-2011 & $-7,308$ & $3.25^{* *}$ \\
\hline & & 2007 & $-9,109$ & $2.65^{* *}$ \\
\hline & & 2011 & $-3,884$ & 1.35 \\
\hline \multirow[t]{3}{*}{ Married_head } & \multirow{3}{*}{$\begin{array}{l}\text { Household head marital status } \\
\text { - dummy }\end{array}$} & 2007-2011 & 486,825 & $4.59^{* *}$ \\
\hline & & 2007 & 432,441 & 2.58 \\
\hline & & 2011 & 527,561 & $4.02^{* *}$ \\
\hline \multirow[t]{3}{*}{ No_income } & \multirow{3}{*}{$\begin{array}{l}\text { Without any income } \\
\text {-dummy }\end{array}$} & $2007-2011$ & $-374,299$ & $2.28^{*}$ \\
\hline & & 2007 & $-833,031$ & 2.16 \\
\hline & & 2011 & $-75,964$ & 0.45 \\
\hline \multirow[t]{3}{*}{ Urban } & \multirow{3}{*}{$\begin{array}{l}\text { Location of residence } \\
\text { - dummy }\end{array}$} & 2007-2011 & $-331,150$ & $5.29^{* *}$ \\
\hline & & 2007 & $-397,740$ & $4.16^{* *}$ \\
\hline & & 2011 & $-227,108$ & $2.81^{* *}$ \\
\hline
\end{tabular}

demographic characteristics on receipt of remittances, particularly place of residence, age, gender, and marital status of a household's head. Married household heads receive more remittance income. Female-headed households also receive more in remittances, which is in line with most previous studies. ${ }^{23}$ Households with an older head receive less remittance income, all else being equal. We also found that several variables used in most of the previous studies, such as a household's size and number of children living in it, were statistically insignificant, so they were excluded in the model's final specification.

The main variable of interest in this study, the variable for social transfers, has a statistically significant and positive coefficient in the model estimated with both 2007 and 2011 data, as well as with 2007 data only. This result suggests that the receipt of social transfers generally increases the amount received through remittances; that is, remittances are primarily driven by the exchange motive. However, this direction changes in 2011, which would indicate that in a situa-

${ }^{23}$ Cf. for example António Gomes Menezes, Inter-Household Private Transfers and Underlying Motives. Evidence for Bulgaria, CEEAplA Working Paper 02/2006, http://www. amenezes.uac.pt/research/bulgaria.pdf. 
Table 3. Estimated coefficients of the alternative models for non-monotonic motives for sending remittances.

\begin{tabular}{|c|c|c|c|c|}
\hline Variables & Explanation & Period & $\begin{array}{c}\text { Coef. } \\
-2007 / 2011\end{array}$ & t-value \\
\hline \multirow[t]{3}{*}{ Incpens1 } & \multirow{3}{*}{$\begin{array}{l}\text { Pre-transfer income } \\
=\text { Income*Pensions }\end{array}$} & 2007-2011 & 6,433 & $2.23^{* *}$ \\
\hline & & 2007 & $-39,420$ & $6.87^{* *}$ \\
\hline & & 2011 & 28,767 & $8.88^{* *}$ \\
\hline \multirow[t]{3}{*}{ Tst1 } & \multirow[t]{3}{*}{ Total social transfers } & $2007-2011$ & 454,985 & $2.82^{* *}$ \\
\hline & & 2007 & 232,713 & 1.05 \\
\hline & & 2011 & $-588,628$ & 1.65 \\
\hline \multirow[t]{3}{*}{ Tst1sq } & \multirow[t]{3}{*}{ Total social transfer squared } & $2007-2011$ & 80,716 & $2.9^{* *}$ \\
\hline & & 2007 & 139,260 & $3.06^{* *}$ \\
\hline & & 2011 & $-27,145$ & 0.39 \\
\hline \multirow[t]{3}{*}{ Poor } & \multirow{3}{*}{$\begin{array}{l}\text { Part of the sample considered } \\
\text { to be poor }\end{array}$} & $2007-2011$ & $-38,529$ & 0.48 \\
\hline & & 2007 & $-495,869$ & $3.78^{* *}$ \\
\hline & & 2011 & 166,602 & 1.68 \\
\hline \multirow[t]{3}{*}{ Tst1poor } & \multirow{3}{*}{$\begin{array}{l}\text { Interaction term - total social } \\
\text { transfer * poor (difference } \\
\text { between poor and non-poor) }\end{array}$} & $2007-2011$ & $-960,766$ & $4.48^{* *}$ \\
\hline & & 2007 & $-758,306$ & $2.66^{* *}$ \\
\hline & & 2011 & 513,757 & 0.77 \\
\hline \multirow[t]{3}{*}{ Fhh_head } & \multirow{3}{*}{$\begin{array}{l}\text { Household head gender } \\
\text { - dummy }\end{array}$} & $2007-2011$ & 735,750 & $6.55^{* *}$ \\
\hline & & 2007 & 346,195 & 1.96 \\
\hline & & 2011 & $1.039,015$ & $7.46^{* *}$ \\
\hline \multirow[t]{3}{*}{ Age_head } & \multirow[t]{3}{*}{ Household head age } & $2007-2011$ & $-7,170$ & $3.15^{* *}$ \\
\hline & & 2007 & $-7,775$ & $2.24^{*}$ \\
\hline & & 2011 & $-4,747$ & 1.63 \\
\hline \multirow[t]{3}{*}{ Married_head } & \multirow{3}{*}{$\begin{array}{l}\text { Household head marital status } \\
\text { - dummy }\end{array}$} & 2007-2011 & 455,482 & $4.26^{* *}$ \\
\hline & & 2007 & 306,574 & 1.82 \\
\hline & & 2011 & 554,079 & $4.19^{* *}$ \\
\hline \multirow[t]{3}{*}{ No_income } & \multirow{3}{*}{$\begin{array}{l}\text { Without any income } \\
\text {-dummy }\end{array}$} & $2007-2011$ & $-386,001$ & $2.35^{*}$ \\
\hline & & 2007 & $-829,186$ & $2.15^{*}$ \\
\hline & & 2011 & $-69,063$ & 0.41 \\
\hline \multirow[t]{3}{*}{ Urban } & \multirow{3}{*}{$\begin{array}{l}\text { Location of residence } \\
\text { - dummy }\end{array}$} & $2007-2011$ & $-337,740$ & $5.40^{* *}$ \\
\hline & & 2007 & $-426,844$ & $4.60^{* *}$ \\
\hline & & 2011 & $-225,124$ & $2.79 * *$ \\
\hline
\end{tabular}

**** significant at $1 \%$ level. ${ }^{* *}$ significant at $5 \%$ level. * significant at $10 \%$ level

tion of worsened economic conditions among recipients, altruism becomes the main motive for sending remittances. This also suggests that remittances are still countercyclical, even when remittance senders are also experiencing the effects of an economic downturn.

Table 3 presents results of the estimation of three models that control for possible non-monotonic motives for remittances. 
In model 3, the benchmark category is that of non-poor households. Consequently, the original coefficient for social transfers measures their effect on receipt of remittances by non-poor households. Its squared term tests the possibility of the nonlinearity of this effect among non-poor households. The coefficient for the interaction term between social transfers and the dummy variable for poor households measures the difference in the effect of social transfers on remittance receipts between the poor and the non-poor. As can be seen from Table 3, the coefficient in front of the tst variable was positive in 2007 and became negative in 2011, which suggests that the main motive for sending remittances to non-poor households changed from exchange in 2007 to altruism in 2011. The squared term was statistically significant in 2007 , but was no longer so in 2011, which shows that the exchange motive was nonlinear, while the altruism motive was not. However, the coefficient in front of the interaction term between social transfers and a household's poverty status (tstpoor) changed its sign from 2007 to 2011, which suggests that the main motive for sending remittances to poor households changed from altruism to exchange.

\section{Conclusions}

The empirical analysis presented above is a first study on the dynamics of motives for sending remittances during a situation of global economic crisis when both senders and recipients of remittances are experiencing a change in income. The results of the analysis should provide useful insight into the existence of a relationship between these two types of transfers and its change over time, possibly as a consequence of the global economic crisis.

The results suggest that the predominant motive for sending remittances to Bosnia-Herzegovina in 2007 was exchange, which changed to altruism in 2011. Remittance receipts during the crisis decreased on average as a result of an increase in social transfers, revealing that remittance payments were influenced by a crowding-out effect caused by social transfers. Controlling for a possible non-monotonic pattern in the motives for sending remittances, the evidence supports the hypothesis that different motives compelled the sending of remittances to poor versus non-poor people. Moreover, the change in motives over time was observed for both poor and non-poor groups: remittances paid to poor people were primarily altruistically motivated in 2007 , but this changed to an exchange motive in 2011, whereas for non-poor households the motives and their change over time showed exactly the opposite pattern.

From a policy perspective, these results suggest that the effect of large, category-based, and inefficient social transfers is made additionally inefficient by the presence of the crowding-out effect on remittances. Consequently, inequality between the recipients and non-recipients of either private or public 
transfers widens further. Finally, inflows of remittances cannot be considered to be a remedy for inefficient forms of social transfer, but on the contrary raise the importance of the proper targeting of social transfers.

\section{CORRESPONDING AUTHOR}

Nermin Oruč Impaq International, Fra Anđela Zvizdovića 1 (Unitic, Building B, 21st floor), 71000 Sarajevo, Bosnia and Herzegovina.Email: nermin.oruc@gmail.com 